\title{
Leaf protein from green pulse crops and nutritive value of legume protein concentrates for poultry
}

\author{
MATTI NÄSI and TUOMO KIISKINEN \\ Department of Animal Husbandry University of Helsinki \\ SF-00710 Helsinki
}

Department of Animal Husbandry Agricultural Research Centre

SF-31600 Jokioinen

\begin{abstract}
Leaf protein concentrate (LPC) samples were prepared from four pulse crops, goat's rue, pea, field bean and Persian clover. Their proximate composition was $42.5-$ $53.4 \%$ crude protein, $2.1-7.9 \%$ ether extract and $1.0-3.0 \%$ crude fibre. The lysine content was $4.1-4.8 \mathrm{~g} / 16 \mathrm{~g} \mathrm{~N}$, that of sulphur amino acids $2.0-2.8 \mathrm{~g}$ and that of threonine $4.5-4.8 \mathrm{~g}$. The contents of tannins varied from 2.2 to $5.5 \%$. The nutritional values of the LPC samples were assesed in digestibility and balance trials with male chickens of $16-18$ weeks, LPC composing $25 \%$ of the diets. LPC from pea had the highest digestibilties of organic matter $(70.3 \%)$, crude protein $(77.6 \%)$ and carbohydrates $(54.9 \%)$, while LPC from Persian clover had the lowest $(\mathrm{P}<0.01)$. The true digestibilities of crude protein for goat's rue, pea, field bean and Persian clover were, respectively, 70.0, 82.2, 69.7 and $56.8 \%$ $(\mathrm{P}<0.01)$. The digestibilities of nutrients in the present LPC samples were rather low compared to their minimal crude fibre content. A reason for this may be the contents of tannins. The $A M E_{N}$ values for the LPC's of goat's rue, pea, field bean and Persian clover were, respectively, 10.79, 13.15, 9.80 and $9.18(\mathrm{P}<0.01)$. The gross energy metabolization ranged from 42.6 to $57.0 \%$.
\end{abstract}

\section{Introduction}

The increasing cost of nitrogenous fertilizers and the need to develop domestic sources of protein for animal consumption have renewed interest in pulse crops in Finland. Peas and field beans have been found to be good sources of protein for pigs and poultry (AlaviuHKola 1979, KiISKINEN 1982). The use of legumes in silages has also been investigated, but the effluent losses have been marked (SYrJäLÄ-Qvist et al. 1984). These losses could be avoided and the protein in plant tissues utilised for monogastrics by combining silage making with leaf protein production by extracting protein from the crop prior to ensiling. The true digestibility and biological value of the leaf protein concentrates (LPC) obtained from some green crops have been found to be high when the 
LPC was prepared under optimal conditions (Morris 1977, PIRIE 1978). LPC from lucerne has given performance equal to that obtained with soybean meal with poultry (KuzMICKY and KOHLER 1977) and pigs (CHEEKE et al. 1977). In diets for poultry LPC has value as a source of pigment (YosHidA and HosHII 1981), since its xanthophyll content is high.

The objective of the present study was to investigate the leaf protein production of various legumes and the nutritive value of leaf protein concentrate in poultry nutrition.

\section{Materials and methods}

Four green pulse crops were used as raw material for LPC production. Goat's rue (Galega orientalis), pea (Pisum sativum), field bean (Vicia faba), and Persian clover (Trifolium resupinatum) were cut with a harvester on experimental plots. Goat's rue had been sowed two years before and the other crops in the same growing season. The fertilizer application was $500 \mathrm{~kg}$ trace $\mathrm{PK}$ per ha.

Extraction involved pulping the green material, pressing out the juice, and separating the leaf protein from the juice by heat coagulation, the techniques being similar to those described by NÄsı (1983 a). For the feed evaluation tests, the curd was dried in an oven at $65^{\circ} \mathrm{C}$. The analytical methods were the same as used in previous leaf protein experiments (NÄSı 1983).

The feed evaluation was made with $36 \mathrm{WL}$ male chickens, age 16-18 wk and initial weight 1610-1676 g, kept in individual cages. Each treatment comprised six cocks. Besides the basic and experimental groups, there was a fasting group, which was kept without feed for 1.5 days, after which collection was performed for three days. The daily allowance of feed was $100 \mathrm{~g}$ and the feed intake was measured daily. The basic diet (No 1) was composed of barley meal $96 \%$ and premix $4 \%$. The premix included dicalcium phosphate $39 \%$, calcium carbonate
$20 \%$, sodium chloride $10 \%$, trace element and vitamin premixes $25.0 \%$, L-lysine $3 \%$ and DL-methionine $3 \%$. The leaf protein concentrates were included in the basic diet at the level of $25 \%$. The birds were allowed to adapt to the diets for five days, after which the excreta were collected daily, for five days. Details of the procedures are presented by KIISKINEN and HUIDA (1984). The nutrient digestibilities of the test feeds and their ME values were calculated from the differences between the values obtained for the basic and test diets by the indirect method of total excreta collection. ME was corrected for the nitrogen balance $\mathrm{ME}_{\mathrm{N}}$ using $36.55 \mathrm{~kJ} / \mathrm{g}$ retained nitrogen (TrTus 1959). The results were evaluated statistically using the analysis of variance. The significance of differences between the test ingredients was assessed by the t-test.

\section{Results and discussion}

The protein yields of the goat's rue and pea crops were high, $760-790 \mathrm{~kg} / \mathrm{ha}$ while field bean and Persian clover gave 330$500 \mathrm{~kg}$ protein/ha (Table 1). The dry matter and protein yields corresponded to the figures given by SYrJÃLÄ-Qvist et al. (1984). On average, $57 \%$ juice was expressed from the green crop. The crude protein and true protein extraction ratios averaged 37 and $33 \%$; the ratios of the pea crop exceeding the others (Table 1). The values were higher than the extractions for grass or clover (NÄsı 1983 a). The crop moisture content has the greatest effect on the recovery of juice and its components (Houseman and Jones 1978). By heating the juice in leaf protein concentrate could be precipitated $58 \%$ of the crude protein and $85 \%$ of the true protein of the juice. These values accord with those of previous experiments with clover and pea, exceeding the values of grass (NÄsı $1983 \mathrm{a}$ ).

The chemical composition and in vitro digestibilities of the crop and pulped pressed crop are compared in Table 2. The DM content was almost as twice high in the pulped 
Table 1. Outline of the experiments, extraction ratios of plant juice and its components from various crops and separation ratios of leaf protein concentrates and its components precipitated from plant juice.

\begin{tabular}{lcccc}
\hline & $\begin{array}{c}\text { Goat's } \\
\text { rue }\end{array}$ & Pea & $\begin{array}{c}\text { Field } \\
\text { bean }\end{array}$ & $\begin{array}{c}\text { Persian } \\
\text { clover }\end{array}$ \\
\hline Outline of the experiments & & & & \\
Cutting date & 21.6 .1982 & 20.7 .1982 & 22.7 .1982 & 28.7 .1982 \\
Fresh yield tn/ha & 18.6 & 19.0 & 21.2 & 12.6 \\
DM yield kg/ha & 3704 & 3610 & 2967 & 2000 \\
Protein yield kg/ha & 760 & 786 & 499 & 329 \\
Pressed amount, kg & 435 & 651 & 531 & \\
Extraction ratios, \% & & & & \\
Juice & 45.9 & 58.4 & 65.6 & 57.1 \\
Dry matter & 19.1 & 32.3 & 31.6 & 28.8 \\
Ash & 35.6 & 38.3 & 41.9 & 39.7 \\
Crude protein & 28.6 & 49.3 & 36.8 & 30.5 \\
True protein & 25.9 & 46.3 & 28.0 & \\
Separation ratios, \% & & & & 17.7 \\
LPC & 19.0 & 21.2 & 8.9 & 29.2 \\
Dry matter & 35.9 & 45.5 & 16.4 & 18.5 \\
Ash & 20.4 & 31.6 & 10.7 & 66.1 \\
Crude protein & 60.8 & 73.2 & 38.6 & 88.6 \\
True protein & 77.0 & 110.0 & 64.1 & \\
\hline
\end{tabular}

Table 2. Compositions and in vitro -digestibility of crop and pulped pressed crop (\% of DM).

\begin{tabular}{|c|c|c|c|c|c|c|c|c|c|c|}
\hline & DM & Ash & $\begin{array}{l}\text { Crude } \\
\text { protein }\end{array}$ & $\begin{array}{c}\text { True } \\
\text { protein }\end{array}$ & $\begin{array}{l}\text { Ether } \\
\text { extract }\end{array}$ & $\begin{array}{l}\text { Crude } \\
\text { fibre }\end{array}$ & NFE & $\begin{array}{c}\text { Water } \\
\text { soluble } \\
\text { carbo- } \\
\text { hydrate }\end{array}$ & $\begin{array}{c}\text { Pepsine } \\
\mathrm{HCl} \\
\text { soluble } \\
\text { protein }\end{array}$ & $\frac{\text { In vitro }}{\text { DOMD }}$ \\
\hline $\begin{array}{c}\text { Goat's r } \\
\text { crop }\end{array}$ & \multicolumn{3}{|c|}{ Goat's rue } & & 2.3 & 23.5 & 45.4 & 7.3 & 71.8 & 71.3 \\
\hline pulp & 30.3 & 5.8 & 18.0 & 14.0 & 2.1 & 30.2 & 43.9 & 4.7 & 68.5 & 66.4 \\
\hline \multicolumn{11}{|l|}{ Pea } \\
\hline crop & 15.1 & 9.4 & 21.8 & 13.1 & 3.2 & 22.8 & 42.8 & 19.5 & 87.2 & 77.8 \\
\hline pulp & 27.3 & 8.0 & 16.5 & 10.9 & 3.1 & 30.4 & 42.0 & 9.1 & 80.5 & 73.1 \\
\hline \multicolumn{11}{|c|}{ Field bean } \\
\hline crop & 14.0 & 9.9 & 16.8 & 12.0 & 2.1 & 24.4 & 46.8 & 19.0 & 83.9 & 77.6 \\
\hline pulp & 28.7 & 6.3 & 13.4 & 11.1 & 2.3 & 33.7 & 44.2 & 8.3 & 73.6 & 69.3 \\
\hline \multicolumn{11}{|c|}{ Persian clover } \\
\hline crop & 15.9 & 11.7 & 16.5 & 11.8 & 3.1 & 17.8 & 51.0 & 15.6 & 83.5 & 80.2 \\
\hline pulp & 26.7 & 8.9 & 16.0 & 12.8 & 3.2 & 23.6 & 48.4 & 8.1 & 77.3 & 75.0 \\
\hline \multicolumn{11}{|l|}{ Mean } \\
\hline Crop & 16.2 & 9.8 & 18.9 & 13.1 & 2.7 & 22.1 & 46.5 & 15.4 & 81.6 & 76.7 \\
\hline Pulp & 28.3 & 7.3 & 16.0 & 12.2 & 2.7 & 29.5 & 44.6 & 7.6 & 75.0 & 71.0 \\
\hline
\end{tabular}

pressed crop and crude fibre one third higher, while the protein content was reduced by only $15 \%$ compared with the original crop. The pulp could be considered suitable material for ensiling and its use would eliminate effluent losses, which have been found to be rather high in the case of pea and field bean used directly after cutting
(SyrJälä-Qvist et al. 1984). The plant juices contained DM 6.8-8.3 \% and the crude protein content was $31-33 \%$ in goat's rue or pea and $19-20 \%$ in bean and clover (Table 3). True protein composed on average $61 \%$ of the crude protein in the juices. The sugar content of the juices was high. NÄsı (1983 b) reported that pea juice deteriorated 
Table 3. The composition of plant juices extracted from various legumes (in percentages).

\begin{tabular}{lcccc}
\hline & $\begin{array}{c}\text { Goat's } \\
\text { rue }\end{array}$ & Pea & $\begin{array}{r}\text { Field } \\
\text { bean }\end{array}$ & $\begin{array}{c}\text { Persian } \\
\text { clover }\end{array}$ \\
\hline Dry matter & 8.31 & 8.33 & 6.84 & 7.99 \\
Ash & 1.27 & 0.93 & 0.90 & 1.29 \\
$\quad$ in DM & 15.3 & 11.2 & 13.2 & 16.2 \\
$\begin{array}{l}\text { Crude protein } \\
\text { in DM }\end{array}$ & 2.55 & 2.77 & 1.34 & 1.50 \\
$\begin{array}{l}\text { True protein } \\
\text { in DM }\end{array}$ & 1.75 & 1.56 & 0.73 & 1.00 \\
$\begin{array}{l}\text { Water soluble } \\
\text { carbohydrates }\end{array}$ & 1.70 & 3.5 .2 & 19.6 & 18.7 \\
$\quad$ in DM & 20.5 & 42.9 & 45.9 & 34.9 \\
\hline
\end{tabular}

very rapidly, pulse crop juices thus being difficult to use in animal feeding.

Goat's rue and pea LPC had a protein content of $52-53 \%$, while LPC derived from field bean or Persian clover had a lower value, $42-46 \%$ of DM. The crude fat content was found to be higher when the ether extraction was preceded by hydrolysis with $\mathrm{HCl}$; Table 5 presents the values of the latter method. There were no great differences in amino acid composition between the sources of LPC. The contents of essential amino acids of the presents LPC samples were lower than the values reported for lucerne LPC (Connell and Foxell 1976, HanczaKOWSKI and SKRABA 1984), but correspond to the values for alfalfa given by CHEEKE et al. (1977). In all the samples in vitro digestibility and solubility in pepsin $\mathrm{HCl}$ were high, 84$89 \%$. KuZMiскy and KoHLER (1977) reported in vitro crude protein digestibilities for four lucerne LPC (Pro-Xan) samples ranging from 87.8 to $97.2 \%$.

The chemical composition and gross energy values of the leaf protein concentrates and the diets are shown in Table 5. GE was higher in pea LPC than in the other concentrates. Diet no. 1, the basic diet, had a slightly lower energy content than the others.

The group of cocks receiving diet no. 3, containing of pea LPC, consumed less $(\mathrm{P}<0.05)$ feed mixture than the others
(Table 6). The reason for this is uncertain, but the animals were a little lighter than those in other treatments. The digestibility of the crude protein of the pea LPC was $77.6 \%$, which was significantly higher than in the other LPC products $(\mathrm{P}<0.05)$. Carbohydrates and organic matter were also more digestible in pea LPC $(\mathrm{P}<0.05)$. Persian clover LPC had the lowest nutrient digestibilities $(\mathrm{P}<0.05)$. In the in field bean and Persian clover products the tannin contents were higher $(5.5-3.0 \%)$ than in pea or goat's rue LPC $(2.7-2.2 \%)$ and this is one probable reason for the differences in digestibility. With peas and field beans (tannins 1.8-2.3\% of DM) Lindgren (1975) found a strong correlation between the digestibility

Table 4. The chemical composition and in vitro digestibility of leaf protein concentrates from various legumes.

\begin{tabular}{|c|c|c|c|c|}
\hline & $\begin{array}{c}\text { Goat's } \\
\text { rue }\end{array}$ & Pea & $\begin{array}{l}\text { Field } \\
\text { bean }\end{array}$ & $\begin{array}{c}\text { Persian } \\
\text { clover }\end{array}$ \\
\hline \multicolumn{5}{|c|}{ Chemical composition, \% of DM } \\
\hline Dry matter & 15.7 & 15.0 & 12.7 & 13.2 \\
\hline Ash & 8.7 & 7.8 & 8.6 & 10.2 \\
\hline Crude protein & 52.0 & 53.4 & 46.1 & 42.5 \\
\hline True protein & 45.2 & 45.3 & 41.7 & 38.0 \\
\hline Ether extract & 4.6 & 7.3 & 2.1 & 7.9 \\
\hline Crude fibre & 1.0 & 2.4 & 3.0 & 2.5 \\
\hline NFE & 33.7 & 29.1 & 40.2 & 36.9 \\
\hline Tannins & 2.2 & 2.7 & 5.5 & 3.0 \\
\hline \multicolumn{5}{|c|}{ Amino acids $\mathrm{g} / 16 \mathrm{~g} \mathrm{~N}$} \\
\hline Alanine & 5.1 & 5.2 & 5.3 & 5.6 \\
\hline Arginine & 5.6 & 5.5 & 5.6 & 5.9 \\
\hline Aspartic acid & 13.4 & 9.4 & 13.1 & 10.8 \\
\hline Cystine & 0.9 & 1.2 & 1.0 & 1.1 \\
\hline Glutamic acid & 10.4 & 10.0 & 10.6 & 10.7 \\
\hline Glycine & 4.5 & 4.6 & 4.8 & 5.1 \\
\hline Histidine & 1.9 & 2.1 & 2.1 & 2.3 \\
\hline Isoleucine & 3.9 & 4.0 & 4.1 & 4.2 \\
\hline Leucine & 7.9 & 8.3 & 8.5 & 8.9 \\
\hline Lysine & 4.8 & 4.3 & 4.1 & 4.4 \\
\hline Methionine & 1.1 & 1.6 & 1.5 & 1.2 \\
\hline Phenylalanine & 4.8 & 5.1 & 5.2 & 5.6 \\
\hline Serine & 4.4 & 4.0 & 4.1 & 4.3 \\
\hline Threonine & 4.7 & 4.5 & 4.6 & 4.8 \\
\hline Tyrosine & 3.4 & 3.9 & 3.8 & 4.0 \\
\hline Valine & 5.2 & 5.2 & 5.0 & 5.5 \\
\hline \multicolumn{5}{|l|}{ In vitro digestibility } \\
\hline \multirow{2}{*}{$\begin{array}{l}\text { Organic matter, } \% \\
\text { Pepsin } \mathrm{HCl} \text { soluble } \\
\text { protein, } \% \text { of } \mathrm{CP}\end{array}$} & 89.5 & 83.5 & 86.4 & 87.2 \\
\hline & 86.4 & 88.6 & 87.1 & 85.3 \\
\hline
\end{tabular}


Table 5. The chemical composition of the LPC's and diets used in the feed evaluation ( $\%$ of DM).

\begin{tabular}{|c|c|c|c|c|c|c|}
\hline & $\begin{array}{c}\text { Dry } \\
\text { matter }\end{array}$ & $\begin{array}{l}\text { Crude } \\
\text { protein }\end{array}$ & $\begin{array}{c}\text { Crude } \\
\text { fat }\end{array}$ & $\begin{array}{l}\text { Crude } \\
\text { fibre }\end{array}$ & Ash & $\begin{array}{c}\mathrm{GE} \\
\mathrm{MJ} / \mathrm{kg} \mathrm{DM}\end{array}$ \\
\hline \multicolumn{7}{|c|}{ Leaf protein concentrate } \\
\hline Goat's rue & 97.5 & 53.9 & 8.1 & 0.6 & 9.0 & 22.33 \\
\hline Pea & 93.2 & 54.6 & 10.7 & 1.0 & 8.0 & 23.08 \\
\hline Field bean & 91.7 & 46.8 & 7.7 & 0.9 & 8.6 & 22.00 \\
\hline Persian clover & 92.9 & 40.5 & 10.1 & 0.6 & 11.2 & 21.55 \\
\hline \multicolumn{7}{|c|}{ Experimental mixtures } \\
\hline Mix no 1 (basic) & 86.3 & 11.4 & 3.3 & 4.1 & 4.6 & 18.00 \\
\hline Mix no 2 & 89.3 & 23.2 & 4.7 & 2.9 & 6.2 & 19.16 \\
\hline Mix no 3 & 88.1 & 22.0 & 5.1 & 3.2 & 5.9 & 19.22 \\
\hline Mix no 4 & 87.8 & 20.4 & 4.5 & 3.2 & 6.7 & 18.84 \\
\hline Mix no 5 & 88.1 & 19.2 & 5.0 & 3.4 & 7.3 & 18.79 \\
\hline
\end{tabular}

coefficient of crude protein and the percent- $73.3 \%$ (KIISKINEN and HUIDA 1984) to age of tannins in crude protein. Leguminous 80-88 \% (Lindgren 1975, AskBrant and seeds have given protein digestibilities from HAKANSSON 1984), but they have a higher

Table 6. Dry matter intake, nitrogen balance, digestibilities of nutrients and calculated ME values (mean $+\mathrm{s} . \mathrm{d}$.$) .$

\begin{tabular}{|c|c|c|c|c|c|}
\hline & $\begin{array}{l}\text { Goat's } \\
\text { rue }\end{array}$ & Pea & $\begin{array}{l}\text { Field } \\
\text { bean }\end{array}$ & $\begin{array}{l}\text { Persian } \\
\text { clover }\end{array}$ & $\begin{array}{c}\text { Basic } \\
\text { diet }\end{array}$ \\
\hline $\begin{array}{l}\text { Dry matter } \\
\text { intake, } \mathrm{g} / \mathrm{d}\end{array}$ & $\begin{array}{c}393.3 \mathrm{a} \\
66.4\end{array}$ & $\begin{array}{c}292.9 b \\
56.7\end{array}$ & $\begin{array}{c}395.1 \mathrm{a} \\
19.9\end{array}$ & $\begin{array}{c}376.4 \mathrm{a} \\
26.5\end{array}$ & $\begin{array}{r}385.8 \\
26.2\end{array}$ \\
\hline $\begin{array}{l}\mathrm{N} \text { balance } \\
\mathrm{mg} / \mathrm{kg} \mathrm{W}\end{array}$ & $\begin{array}{l}9.8 \\
1.8\end{array}$ & $\begin{array}{l}7.4 \\
1.3\end{array}$ & $\begin{array}{l}7.3 \\
2.1\end{array}$ & $\begin{array}{l}8.6 \\
0.9\end{array}$ & $\begin{array}{l}6.8 \\
1.1\end{array}$ \\
\hline $\begin{array}{l}\text { Apparent digestibi } \\
\text { Crude protein }\end{array}$ & $\begin{array}{c}68.0 \mathrm{e} \\
1.6\end{array}$ & $\begin{array}{c}77.6 \mathrm{~d} \\
4.6\end{array}$ & $\begin{array}{c}67.6 \mathrm{e} \\
3.5\end{array}$ & $\begin{array}{c}54.0 \mathrm{f} \\
3.5\end{array}$ & $\begin{array}{r}67.1 \\
2.6\end{array}$ \\
\hline Ether extract & $\begin{array}{r}70.5 \\
2.9\end{array}$ & $\begin{array}{r}72.2 \\
2.9\end{array}$ & $\begin{array}{r}68.0 \\
4.5\end{array}$ & $\begin{array}{r}66.6 \\
4.0\end{array}$ & $\begin{array}{r}57.3 \\
1.2\end{array}$ \\
\hline Carbohydrates & $\begin{array}{c}38.6 \mathrm{~b} \\
6.5\end{array}$ & $\begin{array}{c}54.9 \mathrm{a} \\
6.2\end{array}$ & $\begin{array}{c}39.7 \mathrm{~b} \\
7.2\end{array}$ & $\begin{array}{c}43.5 b \\
4.3\end{array}$ & $\begin{array}{r}81.2 \\
0.73\end{array}$ \\
\hline Organic matter & $\begin{array}{c}58.8 \mathrm{e} \\
2.1\end{array}$ & $\begin{array}{c}70.3 \mathrm{~d} \\
4.2\end{array}$ & $\begin{array}{c}56.4 \mathrm{e} \\
3.4\end{array}$ & $\begin{array}{c}50.9 \mathrm{f} \\
3.1\end{array}$ & $\begin{array}{r}77.0 \\
0.44\end{array}$ \\
\hline $\begin{array}{c}\text { True digestibility, } \\
\text { Crude protein }\end{array}$ & $\begin{array}{c}70.0 \mathrm{e} \\
2.1\end{array}$ & $\begin{array}{c}82.2 \mathrm{~d} \\
4.6\end{array}$ & $\begin{array}{c}69.7 \mathrm{e} \\
3.7\end{array}$ & $\begin{array}{c}56.8 \mathrm{f} \\
3.2\end{array}$ & $\begin{array}{r}75.5 \\
2.2\end{array}$ \\
\hline \multicolumn{6}{|c|}{ Metabolizable energy contents, $\mathrm{MJ} / \mathrm{kg} \mathrm{DM}$} \\
\hline AME class & $\begin{array}{c}11.42 \mathrm{e} \\
0.09\end{array}$ & $\begin{array}{c}13.48 \mathrm{~d} \\
0.62\end{array}$ & $\begin{array}{c}10.12 \mathrm{ef} \\
0.61\end{array}$ & $\begin{array}{l}9.72 \mathrm{f} \\
0.45\end{array}$ & $\begin{array}{r}13.68 \\
0.07\end{array}$ \\
\hline $\mathrm{AME}_{\mathrm{N}}$ & $\begin{array}{c}10.79 \mathrm{e} \\
0.27\end{array}$ & $\begin{array}{c}13.15 \mathrm{~d} \\
0.55\end{array}$ & $\begin{array}{l}9.80 \mathrm{ef} \\
0.55\end{array}$ & $\begin{array}{l}9.18 \mathrm{f} \\
0.56\end{array}$ & $\begin{array}{r}13.43 \\
0.09\end{array}$ \\
\hline \multicolumn{6}{|l|}{ True } \\
\hline TME & $\begin{array}{c}12.04 \mathrm{e} \\
0.46\end{array}$ & $\begin{array}{c}14.83 \mathrm{~d} \\
0.54\end{array}$ & $\begin{array}{c}10.67 \mathrm{ef} \\
0.58\end{array}$ & $\begin{array}{c}10.39 f \\
0.43\end{array}$ & $\begin{array}{r}14.27 \\
0.08\end{array}$ \\
\hline $\mathrm{TME}_{\mathrm{N}}$ & $\begin{array}{c}11.41 \mathrm{e} \\
0.29\end{array}$ & $\begin{array}{c}14.50 \mathrm{~d} \\
0.54\end{array}$ & $\begin{array}{c}10.35 \mathrm{ef} \\
0.52\end{array}$ & $\begin{array}{l}9.89 \mathrm{f} \\
0.50\end{array}$ & $\begin{array}{r}14.03 \\
0.10\end{array}$ \\
\hline $\mathrm{AME}_{\mathrm{N}} \%$ of $\mathrm{GE}$ & 48.3 & 57.0 & 44.5 & 42.6 & 74.6 \\
\hline
\end{tabular}

Means with different letters were significantly different, $a-c(P<0.05)$; $d-f(P<0.01)$. 
crude fibre content, 7-9 \% of DM as compared to $1-3 \%$ in the LPC samples.

The lower digestibility values of LPC products compared with those of seeds of pulse crops are evidently connected with some properties of the leaf proteins or some antinutritional substances in the products.

From a survey of numerous protein quality trials, Morris (1977) concluded that LPC had a satisfactory digestibility and gave biological values and protein efficiency ratios which were consistent with its known aminoacid composition. From rat trials SAUNDERS et al. (1973) and Bickoff et al. (1975) reported in vivo protein digestibilities in rat trials to ranging from $81-91$ and 86 to $94 \%$ for lucerne LPC and the true digestibility values obtained by HANCZAKOWSKI and SKRABA (1984) for the crude protein of LPC samples prepared by different treatments ranged from 76 to $88 \%$. These data are in agreement with the values received for the present pea LPC but exceed the values for the other LPC products. Methionine supple- mentation have improved the biological value of LPC lucerne protein in a study with chicks (HanCZAKOWSKI et al. 1981).

The metabolizable energy values for pea LPC exceeded those for the other LPC products $(\mathrm{P}<0.01$; Table 6$)$. The $\mathrm{AME}_{\mathrm{N}}$ values of the various pulse crop LPC's, 9.213.2 $\mathrm{MJ} / \mathrm{kg} \mathrm{DM}$, are sufficiently high to make these products suitable for poulty feeding. The values for pea LPC are promising. The ME values reported for some leguminous seeds are of the same size order as those for the present LPC products (LINDGREN 1975, KiISKINEN and HuIDA 1984, ASKBRANT and HAKANSSON 1984).

The results presented in this paper indicate that leaf protein from pulse crops can be utilized as a protein supplement in poultry rations, since the amino acid composition is rather promising and the digestibility and metabolization are fairly good, especially in the case of pea LPC. The protein yields and juice extraction from pea were higher than from the other crops.

\section{References}

Alaviuhkola, T. 1979. Herne ja härkäpapu lihasikojen rehuna. Sikatalouskoeaseman tiedote N:o 2. 13 p. Hyvinkäă.

Askabrant, S. \& Hakansson J. 1984. The nutritive value of rapeseed meal, soya bean meal and peas for laying hens. Swedish J. agric. Res. 14: 107-110.

Bickoff, E.M., Booth, A.N., de Fremery, D., Edwards, R.H., Knuckles, B.E., Miller, R.E., SAunders, R.M. \& Kohler, G.O. 1975. Nutritional evaluation of leaf protein concentrate. Protein nutritional quality of foods and feeds. Dekker, New York. pp. 319-340.

Cheeke, P.R., Kinzell, J.H., de Fremery, D. \& KohLER, G.O. 1977. Freeze-dried and commercially -prepared alfalfa protein concentrate evaluation with rats and swine. J. Anim. Sci. 44: 772-777.

Connell, J. \& Foxel., P.R. 1976. Green crop fractionation, the products and their utilization by cattle, pigs and poultry. Bienn. Rev. Natn. Res. Dairy 21: $21-41$.

Hanczakowski, P., Skraba, B. \& Hanczakowska, E. 1981. Nutritive value of lupin-seed protein and leaf-

protein concentrates supplemented with various sulphur sources. Anim. Feed Sci. Technol. 6: 189195.

- \& Skraba, B. 1984. The effect of different precipitating agents on quality of leaf protein concentrate from lucerne. Anim. Feed Sci. Technol. 12: 11-17.

Houseman, R.A. \& Connell, J. 1976. The utilization of products of green-crop fractionation by pigs and ruminants. Proc. Nutr. Soc. 35: 213-220.

KIISKINEN, T. 1982. Kotimaisten siemen- ja yksisoluvalkuaisrehujen ravintoarvo ja käyttömahdollisuudet siipikarjan ruokinnassa. Lisensiaattityö Helsingin yliopisto, kotieläintieteen laitos. $145 \mathrm{p}$.

— \& HuIDA, L. 1984. Metabolizable energy value and digestibility of some protein sources for poultry. Ann Agric. Fenn. 23: 26-38.

Kuzmicky, D.D. \& Kohler, G.O. 1977. Nutritional value of alfalfa leaf protein concentrate (ProXan) for broilers. Poult. Sci. 56: 1510-1516.

Lindgren, E. 1975. The nutritive value of peas and field beans for hens. Swedish J. agric. Res. 5: 159161. 
MorRIS, T.R. 1977. Leaf-protein concentrate for nonruminant farm animals. Occ. Symp. Br. Grassl. Soc. No 9: 67-82.

NÄsı, M. 1983 a. Extraction of leaf protein from green crops. Chemical composition and nutritive value of products of fractionation. J. Scient. Agric. Soc. Finl. 55: 143-154.

- $1983 \mathrm{~b}$. Preservation of grass juice and wet leaf protein concentrate for animal feeds. J. Scient. Agric. Soc. Finl. 55: 465-475.

PIRIE, N.W. 1978. Leaf protein and other aspects of fodder fractionation. 169 p. Camb. Univ. Press. London.

SAunders, R.M., Connor, M.A., Booth, A.N., Bic. KOFF, E.M. \& KOHLER, G.O. 1973. Measurement of digestibility by in vivo and in vitro methods. J. Nutr. 103: $530-535$.

Syrjälä-Qvist, L., Pekkarinen, E. \& Setālã, J. 1984. Vihanta herne ja hărkăpapu sekă niiden viljaseos săilörehun raaka-aineena. Kotielăintieteen laitoksen tiedote No 4. 55 p.

Titus, H.W., Mehring, A.L. Jr., Johnsson, D., Nes. вiтt, L.L. \& Tomas, T. 1959. An evaluation of M.C.F. (Micro-Cel-Fat), a new type of fat product. Poult. Sci. 38: 1114-1119.

Yoshida, M. \& HoshiI, H. 1981. Leaf protein concentrates. Poult. Int. Nov. 106-110.

Ms received January 22, 1985

\section{SELOSTUS}

\section{Vihantapalkokasveista saatu lehtivalkuaistii- viste siipikarjan rehuna}

\author{
Matti Näsi ja Tuomo Kiiskinen \\ Helsingin yliopisto, kotieläintieteen laitos, \\ 00710 Helsinki
}

\author{
Maatalouden tutkimuskeskus, kotieläinhoito-osasto \\ 31600 Jokioinen
}

Tutkimuksessa selvitettiin lehtivalkuaisen eristämistă vuohenherneen, herneen, härkäpavun ja persianapilan vihantakasvustoista ja määritettiin saatujen palkokasvitiivisteiden sulavuus ja muuntokelpoinen energia 16-18 viikon ikäisillă kukoilla kokonaiskeruumenetelmällä. Vesipitoisista vihermassoista saatiin keskimäärin $57 \%$ mehua tuorepainosta. Palkokasvimehut sisälsivät kuiva-ainetta $7.9 \%$ keskimäărin sekä kuiva-aineessa $25.5 \%$ raaka-valkuaista ja $36.1 \%$ sokereita. Lehtivalkuaisissa oli keskimäărin valkuaista $42.6 \%$, rasvaa $5.5 \%$ ja raakakuitua $2.2 \%$. Lysiiniä oli $4.1-4.8$, rikkipitoisia aminohappoja $2.0-2.8$ ja treoniiniả $4.5-4.8$ $\mathrm{g} / 16 \mathrm{~g} \mathrm{~N}$. Valkuaisen pepsiini- $\mathrm{HCl}$ liukoisuus oli kor- kea, $85.3-88.6 \%$. Hernelehtivalkuaisen sulavuudet olivat merkitsevästi korkeampia kuin muiden, kun taas persianapilan lehtivalkuainen suli huonommin kuin toiset. Raakaproteiinin todelliset sulavuudet olivat: $70.0 \%$ vuohenherne, $82.2 \%$ herne, $69.7 \%$ härkäpapu ja $56.8 \%$ persianapila. Tanniinipitoisuudella oli vaikutusta sulavuuteen. Näennäiset muuntokelpoisen energian $\left(\mathrm{AME}_{\mathrm{N}}\right)$ arvot olivat 10.79, 13.15, $9.88 \mathrm{ja} \mathrm{9.18} \mathrm{MJ/kg} \mathrm{ka.,}$ vastaavasti. Hernelehtivalkuaisen sulavuus ja ME -arvo ovat tasoltaan sită luokkaa, ettă sen käyttö olisi mahdollista siipikarjanrehuissa. Lehtivalkuaisen tuotantokustannukset ovat kuitenkin korkeammat kuin muiden nykyisin käytössä olevien proteiinirehujen. 